\title{
AOR
}

Selected Papers of \#AolR2021:

The 22nd Annual Conference of the

Association of Internet Researchers

Virtual Event / 13-16 Oct 2021

\section{MEGAPHONE: SOCIAL-MEDIA-NATIVE OUTLETS BETWEEN EDITORIAL INDEPENDENCE AND ALGORITHMIC CONSTRAINTS}

\author{
Assil Frayha \\ Ph.D Student and CARGC Doctoral Fellow, University of Pennsylvania \\ Marwan M. Kraidy \\ Dean and CEO, Northwestern University Qatar
}

\section{Extended Abstract}

Dubbed the "year of street protests," 2019 witnessed "a tsunami of protests that swept across six continents and engulfed both liberal democracies and ruthless autocracies" (Wright, 2019, para. 1). Protests erupted in places like Hong Kong, Lebanon, Iraq, and Chile to name a few, where people were protesting political establishments that have become all too powerful and all too greedy. Though the role of digital media in protests has received plenty of attention since the onset of Occupy Wall Street and the Arab Uprisings (Penney \& Dadas, 2014; Herrera, 2014; Howard \& Hussain, 2013) a decade ago, the way that protest movements have enabled the institutional development of independent digital news media has received less attention.

How do protest movements enable the rise of independent digital news media? How do these emerging outlets interact with components of pre-existing media? And what techno political constraints do these outlets face? To answer these questions, we zoom in on Lebanon where an uprising broke out in 2019 and gave rise to a network of independent and interdependent digital media outlets. We focus on the rise of Megaphone, an independent social-media-native news outlet that left its mark on the country's political and media scene. Based on a politico-economic analysis of the emerging digital media scene in Lebanon, a historical analysis of the distinctive meaning of media independence in that context, and a case study of Megaphone, we examine the notion of independent digital media in the context of protest movements and look at the distinctive travails of social-media-native outlets.

In October 2019, people from various cities across Lebanon spontaneously took to the streets to call for overthrowing Lebanon's government and entire political ruling class. Though the ostensible trigger was a government decision to charge for WhatsApp

Suggested Citation (APA): Frayha, A., Kraidy, M. (2021, October). Megaphone: Social-Media-Native Outlets Between Editorial Independence and Algorithmic Constraints. Paper presented at AoIR 2021: The 22nd Annual Conference of the Association of Internet Researchers. Virtual Event: AolR. Retrieved from http://spir.aoir.org. 
use-a widely used app for business and social purposes-people were fed up with a ruling class that had drowned the country in sectarianism, corruption, and economic turmoil. The uprising was spontaneous, decentralized, non-violent, and leaderless.

It is in tandem with this moment of rupture that a new imaginary started taking shape at the level of the media. With Lebanon's traditional media outlets being largely owned by, funded by, or affiliated with the ruling elites, revolutionaries relied on the affordances of social media to set up structures for disseminating news and information (Lteif, 2020). Some of that infrastructure was already in place with a number of NGOs, political groups, civil society organizations, and independent digital news outlets already producing critical content online. When the uprising broke out, many of these outlets upped their game and new ones emerged (Merhej and Qureshi, 2020). This gave rise to an organic yet robust network of independent and interdependent digital media outlets which varied in function from covering the events on the ground to facilitating coordination among protestors and became go-to sources for reliable information.

Megaphone is an independent digital news outlet that stood out during that period. It was founded in 2017 by a group of young activists who, frustrated with Lebanon's political establishment and media, were set on creating a platform where they can be critical of the establishment, cover issues that lacked substantial coverage in mainstream media, and amplify the voices of marginalized people and communities who were excluded from mainstream narratives. Their goal was to unpack politics and make it more accessible and engaging to audiences. In order to meet audiences where they were, and having no initial capital, they launched Megaphone as an outlet that was native to social media. Running on volunteer work and anonymity, Megaphone initially engaged in producing slow journalism and published weekly news roundups, monthly videos, and occasional infographics.

When the uprising erupted, Megaphone transformed into a newsroom overnight. They created new formats to document and cover the events on the ground and to provide analysis of the speeches and actions of the ruling elites who tried to delegitimize the uprising or co-opt it. Megaphone's coverage was richer in information, analysis, and insight than that of traditional media outlets. This allowed it to establish itself as one of the main players in Lebanon's digital media scene.

Financially and editorially independent from any political power or influence, Megaphone sustained its activities with the help of grants from local, regional, and international institutions that fund media initiatives. Grants did not compromise the outlet's editorial independence, but some came with their own set of deliverables on themes and number of outputs. Though the internet afforded a low-cost, high-impact infrastructure that enabled independence from political patrons, the complete dependence of outlets like Megaphone on social media platforms introduced new challenges to their work (Prasad, 2019; Salaverría et al., 2018).

As a social-media-native outlet, Megaphone is largely reliant on platforms which host its content and are the primary intermediaries between Megaphone and its audience. In addition to that, the visibility of Megaphone's outputs remains subject to algorithms and platform governance, and its audience remains limited to users of these platforms. 
Despite its anti-establishment discourse, Megaphone has not been officially targeted by any partisan or governmental entities to date. However, it remains vulnerable to mounting pressures from these entities, especially as the ruling elites are managing to hold on to power and the opposition is yet to form a strong and united front.

While we mainly focus on the rise of independent digital media outlets like Megaphone which accompanied Lebanon's 2019 uprising, we also show how, in Lebanon, independence movements, protest movements, and uprisings have historically contributed to introducing new media forms and outlets and shaping Lebanon's media. By analyzing the distinctive travails of social-media-native outlets, our paper contributes to a techno political and algorithmic notion of media independence and begins to theorize social-media-native independent news outlets as a peculiar form of emerging, and increasingly prevalent, media institution (Garcia-Orosa et al., 2020).

\section{References}

Garcia-Orosa, B., Lopez-Garcia, X., \& Vazquez-Herrero, J. (2020). Journalism in Digital Native Media: Beyond Technological Determinism. Media and Communication, 8(2), 515. https://doi.org/10.17645/mac.v8i2.2702

Herrera, L. (2014). Revolution in the age of social media: The Egyptian popular insurrection and the Internet. Verso Trade.

Howard, P. N, \& Hussain, M. M. (2013). Democracy's fourth wave?: Digital media and the Arab Spring. New York: Oxford University Press.

Lteif, D. (2020, July). The Lebanon revolution takes on the media: A resource on alternative news outlets. Jadaliyya. https://www.jadaliyya.com/Details/40379

Merhej, K., \& Qureshi, E. (2020). The Lebanese Uprising in the Digital Age. CyberOrient, 14(2), 85-98. https://doi.org/10.1002/j.1804-3194.2020.tb00004.x

Penney, J., Dadas, C. (2014). (Re)Tweeting in the service of protest: Digital composition and circulation in the Occupy Wall Street movement. New Media \& Society, 16(1), 74-90. https://doi.org/10.1177/1461444813479593

Prasad, R. (2019). Digital disruption? Journalism startups in India. Journalism. https://doi.org/10.1177/1464884919852446

Salaverría, R., Sádaba, C., Breiner, J. G., \& Warner, J. C. (2018). A brave new digital journalism in latin america. (pp. 229-247). Springer International Publishing. https://doi.org/10.1007/978-3-319-91860-0 14

Wright, R. (2019, December). The Story of 2019: Protests in Every Corner of the Globe. The New Yorker. https://www. newyorker.com/news/our-columnists/the-story-of-2019protests-in-every-corner-of-the-globe 